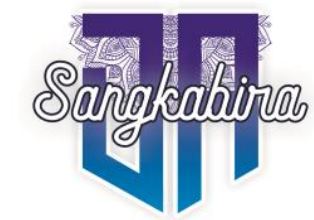

Vol. 2, No. 1, Desember 2021

\title{
MANAJEMEN USAHA DAN KOPERASI PADA UMKM DAN PENGRAJIN GERABAH DI DESA BANYUMULEK KECAMATAN KEDIRI KABUPATEN LOMBOK BARAT
}

\author{
Muhammad Alwi \\ Fakultas Ekonomi dan Bisnis Universitas Mataram \\ alwim5573@gmail.com \\ I Dewa Gde Bisma \\ Fakultas Ekonomi dan Bisnis Universitas Mataram \\ dewa.bisma2016@gmail.com \\ Iwan Kusuma Negara \\ Fakultas Ekonomi dan Bisnis Universitas Mataram \\ iwanegara@yahoo.com \\ Endang Astuti \\ Fakultas Ekonomi dan Bisnis Universitas Mataram \\ e_astuti13@yahoo.co.id
}

\section{Info Artikel}

Diterima:

05-11-2021

Direvisi:

24-12-2021

Diterbitkan:

24-12-2021

\begin{abstract}
Abstrak
Desa Banyumulek memiliki hasil kerajinan tangan yang sudah terkenal dan merupakan salah satu sentra industri kerajinan gerabah yang ada di pulau Lombok. Berbagai jenis kerajinan gerabah yang dibuat di desa ini seperti teko, tong sampah mewah, gentong besar, aneka guci, mangkuk buah, hiasan dinding dan sebagainya. Namun demikian masih lemah dalam manajemen usaha dan koperasi. Kegiatan ini dilaksanakan pada hari Selasa tanggal 12 Oktober 2021 di Aula Desa Banyumulek. Tujuan kegiatan ini adalah memberikan pengetahuan kepada UMKM dan pengrajin Gerabah tentang manajemen usaha dan koperasi. Metode yang digunakan untuk mencapai tujuan ini adalah dengan ceramah dan Focus Group Discussion (FGD) dengan materi manajemen usaha dan koperasi. Hasil dari kegiatan ini adalah UMKM dan pengrajin gerabah sudah dapat mengetahui pentingnya pengetahuan manajemen usaha agar usaha dapat maju dan berkembang kembali. Namun demikian saat ini terjadi kemunduran produksi gerabah yang diakibatkan oleh menurunnya wisatawan yang berkunjung sampai sekarang dan tingginya harga gerabah yang belum mempunyai hak paten, hal ini
\end{abstract}


terjadi karena ketidakamanan dan ketidaknyamananan para pengunjung baik domestik maupun wisatawan Manca Negara. Di samping juga ulah dari pada guide yang meminta $50 \%$ sampai dengan $60 \%$ insentip dari harga jual gerabah kepada pemilik artshop apabila membawa wisatawan belanja pada artshop mereka, akibatnya para pemilik artshop membeli gerabah kepada pengrajin dengan harga yang murah. Koperasi yang ada menjadi macet akibat ketidakjujuran para pengurus sehingga para pengrajin tidak berniat untuk menjadi anggota koperasi. Disarankan kepada UMKM dan Pengrajin gerabah agar dapat mengelola usaha mereka dengan baik dan masuk menjadi anggota koperasi. Pengurus Koperasi harus jujur dalam menjalankan usaha koperasi sehingga koperasi dapat berkembang dan maju.

Kata Kunci: Manajemen usaha dan Koperasi

Abstract
Banyumulek village has well-known handicrafts and is
one of the centers of the pottery industry on the island
of Lombok. Various types of pottery are made in this
village such as teapots, luxury trash cans, large barrels,
various jars, fruit bowls, wall decorations, and so on.
However, it is still weak in business management and
cooperatives. This activity was held on Tuesday,
October 12, 2021, at the Banyumulek Village Hall. The
purpose of this activity is to provide knowledge to
UMKM and pottery craftsmen about business
management and cooperatives. The method used to
achieve this goal is through lectures and Focus Group
Discussions (FGD) with material on business
management and cooperation. The result of this
activity is that UMKM and pottery craftsmen are able to
know the importance of business management
knowledge so that businesses can progress and
develop again. However, at this time there is a decline
in pottery production caused by the decline in tourists
visiting until now and the high price of pottery that
does not have a patent, it happens because of the
insecurity and inconvenience of both domestic and
foreign tourists. Apart from that, it is also the behavior
of the guide who asks for 50 percent to 60 percent of
the incentive from the selling price of pottery to the art
shop owner when bringing tourists shopping to their
art shop, as a result, the art shop owner buys pottery
from the craftsmen at a low price. The existing
cooperation became stuck due to the dishonesty of the




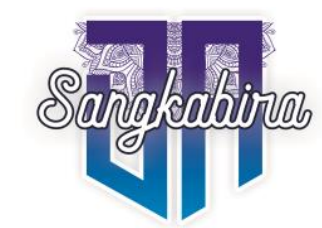

Vol. 2, No. 1, Desember 2021

management so that the craftsmen did not intend to become members of the cooperation. It is recommended to UMKM and pottery craftsmen to be able to manage their business well and become members of the cooperation. The officials of cooperation must be honest in running business cooperation so that the cooperation can develop and progress.

Keyword: Business Management and Cooperation

DOI: $10.29303 /$ abdimassangkabira.v2i1.89

\section{PENDAHULUAN}

Pembangunan masyarakat desa pada hakekatnya merupakan suatu proses perubahan menuju kehidupan yang lebih baik bagi masyarakat Desa, sehingga pada saatnya setiap masyarakat dapat berpartisipasi dan sebagai pelaku pembangunan untuk menunjang pembangunan daerah. Pebangunan desa adalah tanggung jawab seluruh lapisan masyarakat, pemerintah, swasta dan juga tanggung jawab perguruan tinggi beserta civitas akademiknya. Oleh karena itu perguruan tinggi harus dapat menunjang pembangunan desa melalui penerapan ilmu dan tekhnologi.

Di samping itu kompleksitas permasalahan yang terdapat di pedesaan yang dapat menyebabkan tidak segera tercapainya tujuan pembangunan pedesaan. Oleh karena itu sangat diperlukan perhatian berbagai pihak untuk mengatasinya. Desa Banyumulek sebagai salah satu desa yang terdapat di wilayah kecamatan Kediri kabupaten Lombok Barat. Desa Banyumulek merupakan salah satu Desa dari 10 desa yang berada di Kecamatan Kediri Kabupaten Lombok Barat. Desa Banyumulek berjarak tiudak jauh dari pusat pemerintahan kecamatan Kediri dengan luas wilayah $2.816 \mathrm{Ha}$. Mata pencaharian penduduk sebagian besar sebagai petan $(53,69 \%)$, buruh tani $(10,70 \%)$ dan pengrajin gerabah $(21,40 \%)$.

Di desa Banyumulek memiliki hasil kerajinan tangan yang sudah terkenal dan merupakan salah satu sentra industri kerajinan gerabah yang ada di pulau Lombok. Berbagai jenis kerajinan gerabah yang dibuat di desa ini seperti ; teko, tong sampah mewah, gentong besar, aneka guci, mangkuk buah, hiasan dinding dan seabagainya. Pembuatan gerabah masih tetap mempertahankan teknik pembakaran tradisional dengan menggunakan kayu dan jerami. Pemasaran gerabah ini masih sekitar di provinsi NTB dan pulau Bali bahkan sampai di Manca Negara dengan harga bervariasi..

Usaha Mikro Kecil dan Menengah (UMKM) dan pengrajin gerabah banyak tersebar di Desa Banyumulek, akan tetapi belum mempunyai kemampuan untuk memenejmen usaha dengan baik sehingga biasanya menghadapi masalah dalam persediaan bahan baku, stok barang dan 
masalah permodalan. Demikian pula pada para pengrajin ada juga yang menghadapi masalah modal dan pemasaran. Jika hal ini terjadi maka biasanya para pengrajin meminjam pada para rentenir atau para pemilik arshop dengan persyaratan yang telah ditentukan dan bila mengalami masalah pasar maka para pengrajin terpaksa menjual gerabah dengan harga yang murah untuk dapat memenuhi kebutuhan konsumsinya.

Urgensi pengabdian ini dilakukan untuk memecahkan masalah ini, maka perlu pengetahuan tentang manajemen usaha kecil dan wadah yang dapat menjamin perkembangan usaha adalah salah satu diantaranya adalah koperasi atau Kelompok Usaha Bersama (KUBE). Di mana koperasi sangat berperan dalam memajukan perekonomian di daerah pedesaan, namun demikian koperasi yang ada belum berkembang akibatnya para pengrajin dan pemilik artshop tidak maumenjadianggota koperasi. Daerah pedesaan umumnya masih memiliki tingkat pendapatan yang rendah, oleh sebab itu melalui koperasi masyarakat pedesaan akan memperoleh manfaat yang lebih besar dari kegiatan usahanya sehingga kegiatan ekonominya mengalami peningkatan, dengan demikian koperasi benarbenar menjadi salah satu soko guru ekonomi nasional.

Berdasarkan uraian pada analisa situasi tersebut, di mana pengamatan awal yang dilakukan terhadap pengusaha dan pengrajin gerabah dapat diketahui beberapa masalah yang sangat kompleks. Berbagai masalah yang satu dengan yang lainnya saling berkaitan. Adapun permasalahan pokok adalah sebagai berikut :

1. Manajemen usaha masih dilakukan secara tradisional, semua kegiatan yang penting untuk dapat mengembangan usaha ditangani oleh keluarga sendiri.

2. Belum berjalanya koperasi yang sebagai wadah bagi para pengusaha dan pengrajin gerabah untuk membentuk suatu kekuatan yang dapat saling membantu dalam permodalan, pelatihan dan pemasaran hasil produksi

3. Belum ada usaha-usaha untuk meningkatkan kemampuan menajemen pengelolaan usaha dan perluasan pasar.

\section{Tujuan Kegiatan}

Adapun tujuan dilakukannya penyuluhan ini adalah memberikan pengetahuan kepada UMKM dan pengrajin gerabah tentang menejemen usaha dan perkoperasian sehingga mereka mempunyai kemampuan dalam pengembangan usaha, pamasaran, terjaminnya harga hasil produksi kerajinan gerabah dan terpecahkannya masalah permodalan. UMKM dan pengrajin gerabah termotivasi untuk masuk menjadi anggota koperasi

\section{Manfaat Kegiatan}

Manfaat yang diharapkan dari pelaksanaan penyuluhan ini adalah adanya peningkatan kemampuan dalam manejemen pengelolaan usaha dan 


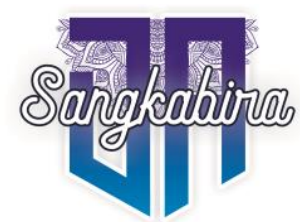

Vol. 2, No. 1, Desember 2021

peningkatan keterampilan dalam mengembangkan usahanya. Di sampingitu pengusaha dan pengrajin dapat bersemangat untuk mendirikan dan masuk menjadi anggota koperasi atau Kelompok Usaha Bersama.

\section{TINJAUN PUSTAKA}

Keberhasilan suatu usaha, apapun bentuk usahanya, sebagian besar bergantung pada kualitas manajemennya. Tujuan suatu oerusahaan akan dapat dicapai apabila perusahaan tersebut memiliki kemampuan manajemen yang koordinasi/pelaksanaan dan pengawasan atas sumber daya manusia dan material untuk mencapai tujuan perusahaan. Aspek ini dipandang penting karena ciri perusahaan kecil yang manajemennya dilaksanakan oleh satu orang dan kecil adalah kurangnya kemampuan manajemen.Aktivitas manajemen melaksanakan.mengkoordinasikan dan mengawasi.

Manfaat Koperasi

Sesuai dengan fungsi dan perannya, koperasi harus mampu memberikan manfaat bagi kehidupan masyarakat terutama kepada para anggotanya.

Berikut ini adalah beberapa manfaat koperasi bagi kehidupan masyarakat, anggota, dan pelaku usaha.

Manfaat Koperasi Bagi Anggotanya:

1. Memberikan kemudahan dan pelayanan yang baik bagi anggota

2. Koperasi minimal harus memberikan kemudahan bagi anggota untuk menikmati fasilitas yang disediakan. Contohnya, saat memberi pinjaman, anggota koperasi harus mendapat prioritas utama untuk diberi pinjaman daripada yang bukan anggota. Atau fasilitas lain, misalnya tingkat bunga yang diberikan kepada anggota harus lebih rendah daripada yang bukan anggota. Dengan begitu, dapat meminimalisir kemungkinan anggota untuk terhindar dari lintah darah.

3. Sarana pengembangan potensi dan kemampuan untuk meningkatkan kesejahteraan anggota Setiap anggota koperasi memiliki kemampuan yang berbeda, seperti dari segi ekonomi atau kemampuan organisasi. Berbagai potensi ini bisa dikembangkan melalui kegiatan berkoperasi. Dengan jasa para anggota, mereka bisa mendapat balas jasa dari koperasi misalnya pembagian sisa hasil usaha (SHU) yang relatif lebih besar. Jika ada anggota koperasi yang kurang memiliki potensi, mereka juga bisa mendapat manfaat seperti pinjaman atau pelatihan. Intinya, kesejahteraan anggota baik yang berpotensi lebih atau tidak berpotensi, tetap dapat ditingkatkan.

4. Mudah merencanakan pengeluaran bagi anggotanya sehingga kualitas hidup meningkat. 
Salah satu kemudahan berbelanja di koperasi adalah karena dapat dibayar belakangan. Maka dengan berbelanja di koperasi, anggota bisa merencanakan pengeluaran terlebih dahulu. Setelah mampu memenuhi semua kebutuhannya, tentu akan memengaruhi kualitas hidup anggota. Dengan kualitas hidup meningkat, kesejahteraan juga ikut meningkat.

5. Melatih kerjasama berorganisasi dan karakter baik lainnya bagi anggota. Kegiatan koperasi biasanya melibatkan banyak orang. Hal ini tentu bisa melatih anggota untuk bekerja sama, berani bersuara dalam rapat, berkoordinasi, dan lain-lain.

Selain itu, prinsip kemandirian koperasi juga membuat anggotanya harus mandiri dan tidak bergantung dengan orang lain.

Manfaat Koperasi Bagi Pelaku Usaha:

1. Memberikan akses untuk mendapat modal usaha

2. Pelaku usaha di Indonesia memiliki beberapa akses dan pilihan untuk memperoleh modal bagi usahanya, contohnya seperti dari Bank Perkreditan Rakyat (BPR). Namun, sebenarnya akses ini lebih mudah didapatkan melalui jalur koperasi. Dengan berbagai syarat yang diajukan pihak perbankan, tentu berbeda dengan koperasi yang syaratnya tidak banyak sehingga bisa memudahkan.

3. Mendapat kesempatan untuk mengikuti pelatihan perkembangan usaha agar kualitas produk dan manajemen UKM meningkat

4. Koperasi adalah prioritas lembaga perekonomian di Indonesia. Maka, ada banyak pelatihan tidak berbayar yang diadakan dari kerjasama koperasi dan lembaga pemerintahan. Seperti pelatihan perizinan usaha, kehalalan, proses ekspor, dan lain sebagainya. Kesempatan ini tentu sangat bermanfaat bagi masa depan usaha, terutama yang masih tergolong sebagai usaha kecil dan usaha menengah.

5. Menumbuhkan kemandirian, disiplin, dan kerjasama untuk peningkatan finansial bagi anggota usaha UMKM yang bergabung ke koperasi dapat memperoleh manfaat berupa etos kerja, seperti kemandirian, disiplin, kerjasama dan lain-lain saat mengembangkan usaha.

Bagi usaha yang belum besar, etos ini sebaiknya ditumbuhkan sejak dini. Bergabung dengan koperasi dapat menumbuhkan etos kerja sehingga perlahan-lahan dapat menjadi budaya perusahaan.

Manfaat Koperasi Bagi Kehidupan Masyarakat Luas:

1. Mengurangi tingkat pengangguran Koperasi membutuhkan banyak pekerja untuk mengelola usahanya. Maka, kehadiran koperasi diharapkan dapat membantu mereka yang membutuhkan pekerjaan.

2. Dapat membantu dan memperkokoh tatanan perekonomian nasional

3. Koperasi merupakan salah satu urat nadi perekonomian bangsa yang harus dikembangkan bersama kegiatan usaha lainnya. 


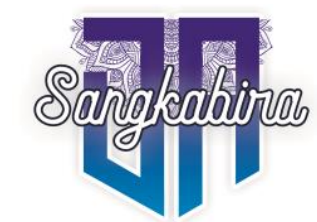

Vol. 2, No. 1, Desember 2021

Maka dengan memberdayakan koperasi, sama artinya dengan memberdayakan masyarakat, kemudian akhirnya dapat memberdayakan perekonomian nasional.

\section{METODE PELAKSANAAN KEGIATAN}

Lokasi pelaksanaan kegiatan pengabdia kepada masyarakat berlokasi di Desa Banyumulek, dengan alasan masih banyak pemilik artshop/UMKM dan pengrajin gerabah tidak dapat memanjemen usaha dengan baik sehingga pemasaran dan pendapatan berkurang. Sebagai sebagai pealaku dalam kegiatan ini adalah dosen Fakultas Ekonomi dan Bisnis Unram dengan sasaran atau objek pengabdian adalah UMKM pemilik artshop dan pengrajin gerabah

Target keluaran yang diharapkan kepada UMKM dan Pengrajin Gerabah di Desa Banyu Mulek Kecamatan Kediri Kabupaten Lombok Barat adalah sebagai berikut :

1. UMKM dan Pengrajin Gerabah sudah dapat memanajemen Usaha Dengan benar

2. UMKM dan Pengrajin gerabah sudah ada pembukuan tentang pembiayaan dan pemasukan dan berusaha untuk mendapatkan hak paten dari produk gerabah banyumulek

3. UMKM dan Pengrajin Gerabah termotivasi untuk masuk menjadi anggota Koperasi

4. Publikasi ilmiah

Untuk mencapai target keluaran dan solusi pemecahan masalah yang dihadapi UMKM pemilik artshop dan pengrajin gerabah, maka metode yang digunakan dalam pelaksanaan pengabdian masyarakat ini dilakukan dalam beberapa langkah berupa :

\section{Persiapan Kegiatan}

1. Melakukan survei pendahuluan ke Desa Banyumulek sebagai lokasi kegiatan pengabdian kepada masyarakat

2. Melakukan koordinasi dengan Sekretaris Desa Banyumulek

3. Pengurusan admidistrasi surat izin pelaksanaan kegiatan pengabdian kepada masyarakat

4. Persiapan alat dan bahan serta akomodisi

5. Persiapan tempat untuk pelaksanaan FGD ( focus group discussion )

\section{Kegiatan FGD ( Focus group discussion )}

1. Pengantar sambutan Kepala Desa Banyumulek

2. Sambutan ketua tiam pelaksana kegiatan pengabdian masyarakat.

3. Penyampaian materi penyuluhan tentang :

- Menyampaikan pengetahuan Kewirausahaan, menajemen usaha kecil dan koperasi.

- Tujuan dan Manfaat masuk menjadi anggota koperasi dan Kelompok Usaha Bersama atas dasar start up. 
- Upaya untuk meningkat Pemasaran ekonomi

4. Penyampaian masalah atau pertanyaan bagi para peserta kegiatan pengabdian kepada Tim Pengabdian kepada masyarakat

\section{HASIL KEGIATAN}

Desa Banyumulek merupakan salah satu Desa dari 10 desa yang berada di Kecamatan Kediri Kabupaten Lombok Barat. Desa Banyumulek berjarak tiudak jauh dari pusat pemerintahan kecamatan Kediri dengan luas wilayah $2.816 \mathrm{Ha}$. Mata pencaharian penduduk sebagian besar sebagai petan $(53,69 \%)$, buruh tani $(10,70 \%)$ dan pengrajin gerabah $(21,40 \%)$. Desa Banyumulek terdiri atas 10 Dusun dengan berbagaimacam potensi selain menjadi sentra industri gerabah juga mempunya potensi taman bunga yang indah, sumur tua dan kuburan/makam pemulek serta pasar seni.

Di desa Banyumulek memiliki hasil kerajinan tangan yang sudah terkenal dan merupakan salah satu sentra industri kerajinan gerabah yang ada di pulau Lombok. Berbagai jenis kerajinan gerabah yang dibuat di desa ini seperti ; teko, tong sampah mewah, gentong besar, aneka guci, mangkuk buah, hiasan dinding dan seabagainya. Pembuatan gerabah masih tetap mempertahankan teknik pembakaran tradisional dengan menggunakan kayu dan jerami. Pemasaran gerabah ini masih sekitar di provinsi NTB dan pulau Bali bahkan sampai di Manca Negara dengan harga bervariasi dari Rp. 10.000 sampai dengan Rp. 300.000 tergantung jenis, motif dan tingkat kesulitan membuatnya.

Usaha Mikro Kecil dan Menengah (UMKM) dan pengrajin gerabah banyak tersebar di Desa Banyumulek,akan tetapi belum mempunyai kemampuan untuk memenejmen usaha dengan baik sehingga biasanya menghadapi masalah dalam persediaan bahan baku, stok barang dan masalah permodalan. Demikian pula pada para pengrajin ada juga yang menghadapi masalah modal dan pemasaran. Jika hal ini terjadi maka biasanya para pengrajin meminjam pada para rentenir atau para pemilik arshop dengan persyaratan yang telah ditentukan dan bila mengalami masalah pasar maka para pengrajin terpaksa menjual gerabah dengan harga yang murah untuk dapat memenuhi kebutuhan konsumsinya.

Urgensi pengabdian ini dilakukan untuk memecahkan masalah ini, maka perlu ada pengetahuan tentang manajemen usaha kecil dan suatu wadah yang dapat menjamin perkembangan usaha adalah salah satu diantaranya adalah koperasi atau Kelompok Usaha Bersama (KUBE). Di mana koperasi sangat berperan dalam memajukan perekonomian di daerah pedesaan. Daerah pedesaan umumnya masih memiliki tingkat pendapatan yang rendah, oleh sebab itu melalui koperasi masyarakat pedesaan akan memperoleh manfaat yang lebih besar dari kegiatan usahanya sehingga kegiatan ekonominya mengalami peningkatan, dengan 


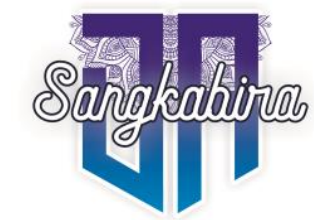

Vol. 2, No. 1, Desember 2021

demikian koperasi benar-benar menjadi salah satu soko ajin guru ekonomi nasional.

Pelaksanaan kegiatan pengabdian masyarakat dilaksanakan pada hari Selasa tanggal 12 Oktober 2021. Kegiatan ipengabdian ini dilaksanakan di Aula Desa Banyumulek Jumlah peserta yang hadir kegiatan ini sebanyak 16 Orang pengrajin Gerabah dan UMKM, kepala Desa dan Kadus.

Materi yang disampaikan adalah manajemen usaha Karena keberhasilan suatu usaha apapun bentuk usahanya, sebagian besar tergantung pada kualitas manajemennya usah baik usaha bisnis besar maupun usaha bisnis kecil . Disamping Mmanajemen usaha juga cara mengelolah kopersi agar berhasil dalam usahanya. Pembarian materi ini mendapat respon yang positif dari para peserta ditandai dengan antusiasnya para peserta bertanya kepada tiam penyuluh yang berhubungan dengan manajemen usaha baik aspek produksi maupun aspek pemasaran. dan juga tentang koperasi.yang sudah ada tetapi sampai sekarang masih macet.

Pada tahap diskusi berbagai masalah yang ditanyakan oleh seperti permodlan, tempat usaha, pemasaran dan ekonomi kreatif. Adapun nama, usaha dan masalah yang dihadapi para peserta seperti dalam tabel berikut ini :

Tabel 1. Usaha, masalah dan Pertanyaan Peserta Kegiatan ini.

\begin{tabular}{|c|c|c|c|}
\hline No & Nama & Usaha & Masalah dan petanyaan \\
\hline 1 & Jainuddin & $\begin{array}{ll}\text { Ketua Pasar } & \text { Seni } \\
\text { Banyumulek } & \end{array}$ & $\begin{array}{l}\text { Masalah rendahnya SDM } \\
\text { pengrajin } \\
\text { sehingga mempengabuhi } \\
\text { pengeloan usaha dalam } \\
\text { menjalankam usaha dan } \\
\text { pengambilan keputusan. } \\
\text { Koperasi sudah ada karena } \\
\text { keterbatasan SDM dan } \\
\text { kejujuran dari pengurus } \\
\text { sehingga koperasi tidak } \\
\text { berjalan baik dan } \\
\text { membantu anggota } \\
\text { koperasi. Belum ada } \\
\text { pencatatan pembelian } \\
\text { anggota koperasi sehingga } \\
\text { tidak intensip bagi anggota } \\
\text { pada hari hari besar islam.. } \\
\text { Terjadi persaingan harga } \\
\text { dan kualitas gerabah oleh } \\
\text { sesama pengrain }\end{array}$ \\
\hline 2 & Ahmad Mujahidin & $\begin{array}{l}\text { Pemilik Artshop juga } \\
\text { terkadang sebagai quide }\end{array}$ & $\begin{array}{l}\text { Apa tujuan dan fungsi Hak } \\
\text { Paten' }\end{array}$ \\
\hline
\end{tabular}




\begin{tabular}{|c|c|c|c|}
\hline & & dan sebagai instruktur & $\begin{array}{l}\text { Keamanan yang bagaimana } \\
\text { yang dimaksud } \\
\text { Apasebab Banyumulek } \\
\text { Mundur. } \\
\text {-Banyak pungutan liar } \\
\text {-Guide yang meminta \% } \\
\text { yang cukup tinggi sehingga } \\
\text { memaksa pemilik Artshop } \\
\text { menjual gerabah dengan } \\
\text { harga yang tinggi atau } \\
\text { membeli gerabah ke } \\
\text { pengrajin dengan harga } \\
\text { yang sangat murah. }\end{array}$ \\
\hline 3 & Marzuki & Kadus Muhajirin & $\begin{array}{l}\text { Dusun Muhajirin sebagai } \\
\text { pusat pembuatan gerabah } \\
\text { di Banyumulek, sedang } \\
\text { disiapkan untuk memasang } \\
\text { gerabah di tengah-tengah } \\
\text { Dusun sebagai simbol } \\
\text { Banyumulek sebagai Desa } \\
\text { Wisata yang diharapkan } \\
\text { bisa membuat Banyumulek } \\
\text { kembali terkenal seperti } \\
\text { dulu. }\end{array}$ \\
\hline 4 & Rahmat & Pemilik Artshop & $\begin{array}{l}\text {-Sejak Boom Bali mulai } \\
\text { terjadi penurunan jumlah } \\
\text { wisatawan yang datang ke } \\
\text { Banyumulek hingga masa } \\
\text { pandemic covid } 19 \text { yang } \\
\text { berimbas pada penghasian } \\
\text { I dari pengrajin Gerabah. } \\
\text {-Prilaku Guide yang } \\
\text { meminta \% hinggga } 50-60 \\
\% \text { dari harga gerabah saat } \\
\text { membawa wisatawan. Hal } \\
\text { ini sangat membebani } \\
\text { pemilik Artshop akibat } \\
\text { gerabah yang menjadi } \\
\text { sangat mahal, sedangkan } \\
\text { pemilik artshop membelih } \\
\text { gerabah pengrajin dengan } \\
\text { harga yang murah.. } \\
\text { - Pembayaran yang } \\
\text { tertunda yang terkait } \\
\text { pengiriman gerabah ke luar } \\
\text { Banyumulek sehinggga } \\
\text { akan mengganggu proses }\end{array}$ \\
\hline
\end{tabular}




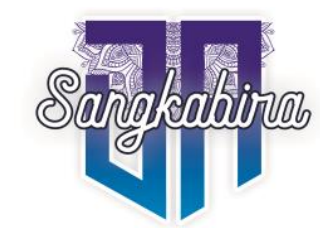

Vol. 2, No. 1, Desember 2021

\begin{tabular}{|l|l|l|}
\hline & & $\begin{array}{l}\text { produksi dan penghasilan } \\
\text { pengrajin. }\end{array}$ \\
\hline
\end{tabular}

Sumber : Peserta Kegiatan Pengabdian Pada Masyarakat

Berdasarkan masalah pertanyaan yang yang dihadapi oleh para UMKM dan Pengrajin gerabah di atas kami tiam pengabdian masyarakat menyampaikan beberapa solusi atau tanggapan antara, agar manajemen usaha yang dilakukan lebih baik lagi sehingga UMKM dan pengrajin gerabah dapat berkembang dan jaya seperti dulu. Meskipun manajemen usaha sudah bisa dilakukan tetapi harus diiciptakan terus suasana keamanan dan kenyaman sehingga wisatawan mau datang berwisata ke Banyumulek yang dulunya jumlah wisatawan menurun akibat keamanan dan keamanan tidak terjaga. Dalam melakukan promosi hasil kerajinan gerabah atau mengirim gerabah ke luar negeri starategi yang harus dilakukan menitipkan beberapa miniatur produk gerabah yang terbaru/inovasi kepada pembeli di luar sehingga secara tidak langsung ikut membantu mempromosikan prosuk tersebut dan tetapa memperhatikan keinginan/selera konsumen atau perkembangan pasar. Untuk menjaga terjadi persaingan harga akibat tingkah laku dari para guide yang selalu ingin mendapatkan balas jasa dari hasil penjualan pemilik artshop samapai $50 \%$ dari harga jual gerabah. Akibat pemilik artshop menaikan harga jual dan membeli gerabah dengan harga murah pada pengrajin gerabah. Untuk memecahkan masalah ini, maka perlu duduk bersama antara semua pemilik artshop, pengrajin gerabah dan guide untuk membuat kesepatan bersama sehingga terjadi saling menguntungkan. Dalam berkoperasi yang ada hendaknya pengurus dan pengelolah mengutamakan dan memperhatikan sifat kejujuran sehingga akan dapat bermanfaat bagi pengurus/pengelolah dan para anggota, disarankan agar semua pengrajin masuk menjadi anggota koperasi.. Semua pengurus, pengelolah, anggota koperasi harus meneladani sifat sifat Rasulullah Muhammad SAW yaitu siddik, fatonah dan amanah sehingga koperasi yang menjadi maju dan berkembang.

Bagi pengrajin dan pemilik artshop harus dapat mengurus hak paten supaya kedepannya produk gerabah menjadi milik Banyumulek yang akan menjadi lebih terkenal. Pengurusan hak paten bisa minta bantuan kepada LPPM Unram bersama kepala Desa Banyumulek. Hak paten itu bisa diminta dari sisi mereknya, hasil produksi atau dari sisi proses pembuatannya. Untuk mengetahui apa starategi apa yang harus dilakukan agar produk gerabah Banyumulek lebih maju dan berkembangng, maha harus menggunakan analisis SWOT untuk dapat menetahui kekuatan, kelemahan, peluang dan ancaman bagi produk gerabah banyumulek. 


\section{KESIMPULAN DAN SARAN \\ Kesimpulan}

1. Para peserta pengrajin gerabah dan UMKM pemilik artshop sudah mengetahui akan manfaat dan pentingnya manajemen usaha dan koperasi agar usaha gerabah dapat maju dan berkembang di masa datang, namun demikian UMKM dan pengrajin belum tahu manajen usaha yang benar.

2. Banyak potensi yang dimiliki oleh Desa Banyumulek selain sebagai sentra produksi gerabah, juga memilik potensi yang lain seperti taman bunga, sumur tua dan kuburan makam Mulek.

3. Sumberdaya manusia pangrajin gerabah masih rendah sehingga mengelolaan usaha dan pengabilan keputusan kurang tepat.

4. Koperasi sudah ada, akan tetapi tidak dapat berjalan karena keterbatasan sumberdaya manusia sebagai pengelolah dan ketidak jujuran para pengelolah menyebabkan pengrajin tidak mau masuk menjadi anggota koperasi.

5. Desa Banyumulek tidak terkenal lagi seperti dulu sebagai penghasil gerabah ditandai dengan kunjungan wisatawan menurun, di samping akibat tidak aman dan tidak nyaman para wisatawan serta tingginya harga gerabah diartshop akibat guide minta persesate $50 \%$ sampai 60 $\%$ dari harga gerabah sehingga para memilik artshop membeli gerabah pada pengrajin gerabah dengan harga yang murah serta hak paten gerabah Banyu mulek belum ada sampai saat ini..

\section{Saran-Saran}

1. UMKM dan pengrajin gerabah hendak belajar terus memanajen usaha agar usaha dapat maju dan berkembang pesat.

2. Para pengurus koperasi yang dapat mengeloh kepersasi dengan baik dengan cara belajar manajemen usaha dan hendak para pengurus memiliki kejujuran sehingga diharapkan para pengrajin gerabah tertarik untuk menjadi anggota koperasi.

3. Pemerintah atau aparat Desa menindak tegas bagi penduduk yang membuat ketidak amanan dan ketidak nyaman wisatwan agar wisatwan terkenal seperti dulu dan tidak boleh ada permainan harga,

4. Pihak pemilik artshop, pengrajin gerabah, guide agar duduk bersama untuk membicarakan intesip guide, harga gerabah pada pengrajin sehingga sama mendapatan yang seimbang.

5. Untuk menjaga bahwa gerabah ciptaan Desa Banyumulek lebih dikenal baik wisatawan dalam negeri maupun wisatawan luar negeri maka hendaknya memiliki hak paten.

\section{Daftara Pustaka}

Alma Buhchari, 2002. Kewirausahaan, Penerbit Alfabeta. Bandung Sattar, 2017. Buku Ajar Ekonomi Koperasi, Penerbit Deepublish, Yoyakarta 